\title{
Peritoneal mesothelioma and malignant lymphoma in mice caused by fibrous zeolite
}

\author{
M ÖZESMI , ${ }^{1}$ T E PATIROGLU, ${ }^{2}$ G HILLERDAL, ${ }^{3}$ AND C ÖZESMI ${ }^{4}$
}

From the Medical Faculty, ${ }^{1}$ Department of Internal Medicine, Department of Pathology, ${ }^{2}$ and Research Centre, ${ }^{3}$ Ercyies University, Kayseri, Turkey, and the Department of Lung Medicine, ${ }^{4}$ University of Uppsala, Academic Hospital, Sweden

ABSTRACT Dust from the village of Karain containing the fibrous zeolite erionite, talc, and physiological saline were tested by intraperitoneal injection in 486 Swiss albino mice. Malignant tumours were found in 84 (41 mesotheliomas, 31 lymphomas, 1 peripheral epidermoid carcinoma, and 11 lymphomas and mesotheliomas together) of the 321 animals which died spontaneously within nine to 32 months after injection of Karain dust (26.1\%). Three mesotheliomas and no lymphomas were found among 24 animals injected in the same way with talc during the same time (12.5\%). In 46 control animals injected with physiological saline three mesotheliomas and one lymphoma were seen (8.7\%). Thus Karain dust appears to be a potent carcinogen, causing both mesotheliomas and malignant lymphomas.

Since 1974 the Baris group from Hacettepe University of Ankara, Turkey, has worked on the problem of mesotheliomas in middle Anatolia, where in certain villages there is an endemic occurrence of this disease. The highest incidence is in the village of Karain. ${ }^{1}$ Volcanic tuffs form the bedrock of the area. In the villages with a high incidence of mesothelioma the tuffs have converted into zeolites, both non-fibrous (clinoptilolite and chabasite) and fibrous (erionite and mordenite. ${ }^{23}$ Erionite fibres can also be found in biopsies of the lung ${ }^{24}$ and pleura ${ }^{4}$ in inhabitants of the affected villages. Since some doubt as to the causation of the mesotheliomas still remains, ${ }^{56}$ it was decided to carry out some experiments beginning in 1980.

\section{Material and methods}

A rock from Karain was ground to dust at the Geological Institute of Hacettepe University. In this Karain dust (KD) zeolite was shown, both in fibrous and non-fibrous form. There were no signs of any asbestos in the dust. The dust was divided into packages of $5,10,15,20,30$, and $40 \mathrm{~g}$ and suspended in $1 \mathrm{ml}$ of physiological saline and sterilised with ultraviolet light. Commercial talc, $20 \mathrm{mg}$, was treated in

Received 25 February 1985

Accepted 25 March 1985 the same way. The suspensions were injected into 6 week old Swiss albino mice. As a control, $1 \mathrm{ml}$ of physiological saline was used in several animals.

The animals were checked every day until spontaê neous death occurred or until there were obviouझ signs of tumour, such as a greatly enlarged abdomen. Animals which died before nine months had elapsed after injection were excluded.

Postmortem examination was performed on all dead animals. Macroscopical findings were noted and biopsy specimens from the injection site, parietal and visceral peritoneal mesothelium, peritoneal lymph nodes, spleen, liver, kidneys, adrenals, mediastinal lymph nodes, and tumours were taken for microscopical investigation. The pathologist was unaware of the type of dust to which the animals had been exposed.

\section{Results}

As seen in the table, KD caused tumours in $26.1 \%$, talc in $12.5 \%$, and physiological saline in $8.7 \%$ of the animals. There was no evident relation between the amount of dust and the incidence of tumours. No tumours occurred before nine months had elapsed after injection.

Of the 321 animals given KD, mesothelioma developed in 41 , lymphoma in 31 , peripheral epidermoid carcinoma in one, and both lymphoma and mesothelioma in 11. Thus in all there were 52 meso- 

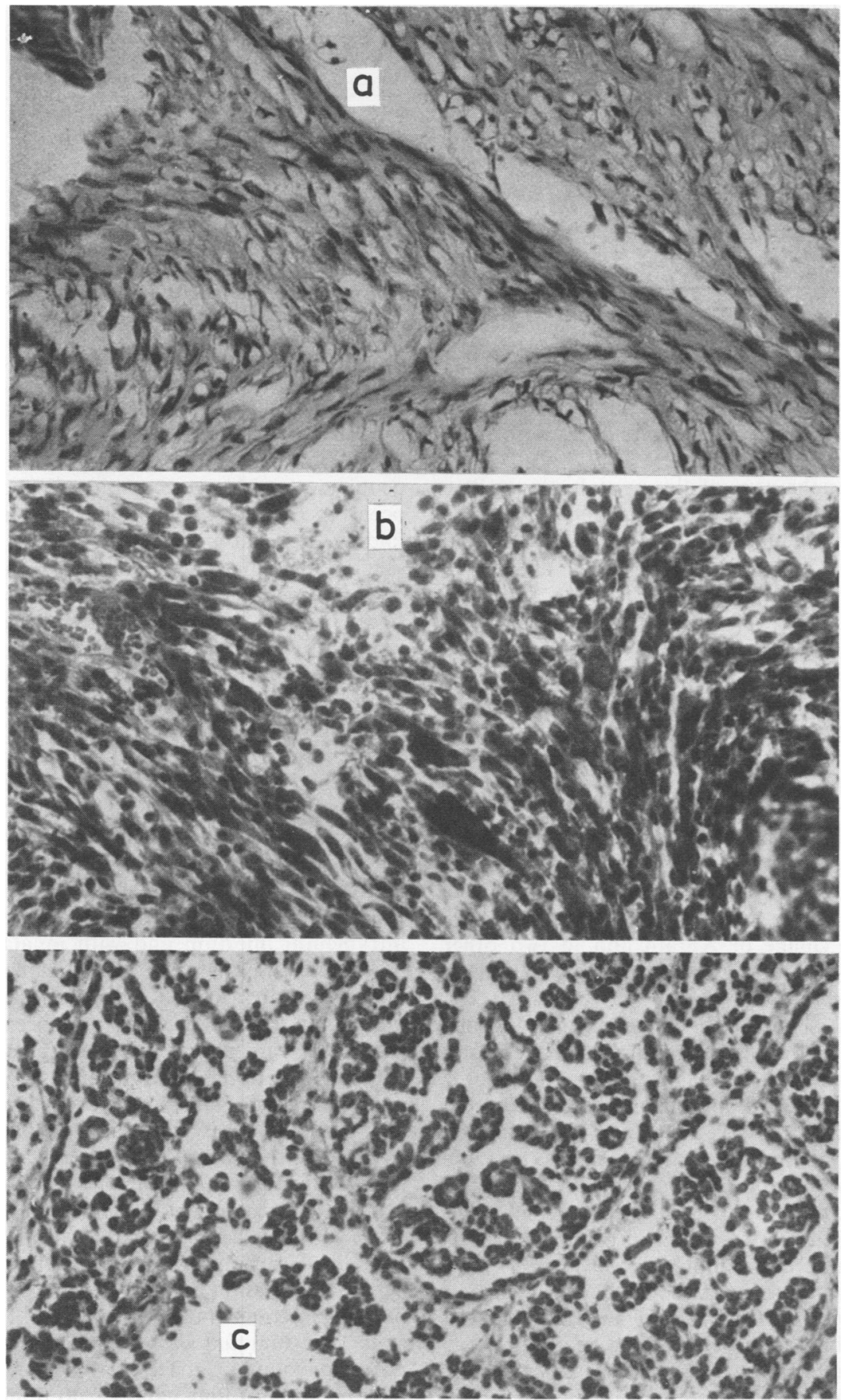

Peritoneal mesotheliomas in mice: (A) fibrous mesothelioma with few mitoses, $(B)$ sarcomatous type, (C) epithelial mesothelioma. (HE stain; original magnification $\times 400$.) 
Results of intraperitoneal injection of Karain dust (KD) and of talc into mice

\begin{tabular}{|c|c|c|c|c|c|c|c|c|}
\hline $\begin{array}{l}\text { Injected } \\
\text { material }\end{array}$ & $\begin{array}{l}\text { No of } \\
\text { mice }\end{array}$ & $\begin{array}{l}\text { Dead before } \\
\text { six months }\end{array}$ & Remaining & Mesothelioma & Lymphomas & $\begin{array}{l}\text { Both lymphoma } \\
\text { \& mesothelioma }\end{array}$ & $\begin{array}{l}\text { Total } \\
\text { tumou }\end{array}$ & $\%$ \\
\hline $\begin{array}{l}\text { Saline } \\
5 \mathrm{mg} \mathrm{KD} \\
10 \mathrm{mg} \mathrm{KD} \\
15 \mathrm{mg} \mathrm{KD} \\
20 \mathrm{mg} \mathrm{KD} \\
30 \mathrm{mg} \mathrm{KD} \\
40 \mathrm{mg} \mathrm{KD} \\
\text { All KD } \\
\text { Talc }(20 \mathrm{mg})\end{array}$ & $\begin{array}{r}55 \\
69 \\
97 \\
98 \\
45 \\
45 \\
37 \\
391 \\
40\end{array}$ & $\begin{array}{r}9 \\
14 \\
16 \\
25 \\
2 \\
6 \\
7 \\
70 \\
16\end{array}$ & $\begin{array}{r}46 \\
55 \\
81 \\
73 \\
43 \\
39 \\
30 \\
321 \\
24\end{array}$ & $\begin{array}{r}3 \\
6 \\
12 \\
10 \\
6 \\
3 \\
4 \\
41 \\
3\end{array}$ & $\begin{array}{r}1 \\
11 \\
7 \\
5 \\
4 \\
4 \\
31 \\
-\end{array}$ & $\begin{array}{r}0 \\
4 \\
4 \\
0 \\
1 \\
2 \\
11 \\
-\end{array}$ & $\begin{array}{c}4 \\
10 \\
27 \\
17 \\
12^{*} \\
8 \\
10 \\
84^{*} \\
3\end{array}$ & $\begin{array}{l}8 \cdot 7 \\
18 \cdot 1 \\
33 \\
23 \cdot 3 \\
28 \\
20 \cdot 5 \\
33 \\
26 \cdot 1 \\
12 \cdot 5\end{array}$ \\
\hline
\end{tabular}

* One animal had an epidermoid tumour of the lung.

theliomas (16.5\%), and 42 lymphomas (13.3\%). All types of mesotheliomas (fibrous sarcomatous, and mixed) were seen (figure). The lymphomas were of the malignant lymphomatous type.

Depending on the stage of disease at death, the liver or spleen, or both, were often invaded in both types of tumours, and in some cases there were also distant metastases.

\section{Discussion}

The first international report from the village of Karain was published by Baris et al in $1978 .{ }^{1}$ Extremely high incidences of malignant mesothelioma and benign pleural changes were reported, but apart from some asbestos fibres in some of the water used in the village (a finding which has not since been confirmed ${ }^{7}$ ), no mineral fibres had been found in the environment to that date. The extensive subsequent investigations showed that fibrous zeolites, the most important of which is erionite, were present in the village of Karain and in two other villages-Tuzköy and Sarihidir-where mesotheliomas also occur. ${ }^{248}$

There is still some doubt as to whether fibrous zeolite is the cause of the malignant mesotheliomas in this part of Turkey, and it has been suggested that it is mixed fibrous dust, containing asbestos fibres in addition to erionite, that is the culprit. ${ }^{56}$ It has been claimed that there is some asbestos in the surroundings of Karain, ${ }^{5}$ and lung biopsy specimens from patients from Karain contained other fibres in addition to erionite. ${ }^{6}$ Measurements of the fibre levels in environmental air samples from Karain have shown such low figures ${ }^{7}$ that doubt has been cast on their importance. Furthermore, it has been claimed that erionite fibres may be found in nearby villages where there are no known cases of mesotheliomas. ${ }^{5}$ In an investigation by Mumpton, 15 of 28 probes from the three villages showed erionite fibres, whereas only four of $\mathbf{4 8}$ from control villages showed such fibres. ${ }^{9}$ Förster has since reported that zeolites occur only in the northern part of Karain, ${ }^{3}$ whereas the probes in Mumpton's study were taken in the southern part.

Asbestos fibres may be seen in the lungs of many people even without occupational exposure and their occurrence in people from Karain could be a chance finding. The vast majority of the fibres in the lungs of the Turkish villagers were erionite, and only a small minority were asbestos. ${ }^{56}$ In patients from Tuzköy fibres of erionite in high concentrations and ferruginous bodies on erionite have been found. ${ }^{10}$ Mesotheliomas in experimental animals after intrapleural or intraperitoneal injection or even inhalation of erionite have also been shown. ${ }^{11-13}$

The results of the present study confirm that dusto from Karain is carcinogenic, and since it contained noasbestos it seems most probable that it is the erionite that caused the mesotheliomas. Maltoni et al state that pure erionite injected intrapleurally in rats causes mesothelioma in the pleura in $90 \%$ of the cases, ${ }^{11}$ and Wagner reported $100 \%$ of mesotheliomas with both intrapleural injection and with inhalation. ${ }^{13}$ In the present material the frequency of tumours was not as high, since dust from Karain was used rather than pure erionite, and perhaps also because the intraperitoneal rather than the intrapleural route was chosen. According to Maltoni et al, erionite causes more mesotheliomas than crocidolite, which is generally considered to be the most dangerous type of asbestos in this regard. ${ }^{11}$ Wagner states that erionite is the only dust so far known to cause mesotheliomas in $100 \%$ of experimental animals on inhalation. ${ }^{13}$

An unexpected observations was the relatively common occurrence of malignant lymphomas in the experimental animals. There are no epidemiological findings to confirm this. Artvinli and Baris, however, state that tumours other than mesotheliomas may not be uncommon in Tuzcöy. ${ }^{4}$ So far, however, with the exception of lung cancer, ${ }^{7}$ no tumour other than malignant mesothelioma has been shown to have an increased incidence in the zeolite area.

Suzuki used two types of American erionite (from 
Nevada and Colorado), which on intraperitoneal injection caused malignant peritoneal tumours in $50 \%$ of the animals, ${ }^{12}$ a frequency higher than that among animals injected with asbestos (33\% with amosite and $17 \%$ with crysotile). Of the 39 animals with erionite induced malignant peritoneal tumours, five had plasmocytomas, and in two other animals mesothelioma was combined with plasmocytoma. There were no plasmocytomas or lymphoid tumours in the animals exposed to asbestos. Thus erionite seems to be able to cause tumours of the lymphoid system, which fits with the present results.

From a study with intraperitoneal inoculation and inhalation of asbestos, Wagner reported some lymphosarcomas. ${ }^{14}$ All animals that had received asbestos showed pronounced stimulation of the reticular endothelial system. Tumours of the haematopoietic and lymphatic systems have also been described in people exposed to asbestos. ${ }^{15}$ Since the effects of erionite are thought to be similar to those of asbestos, stimulation of the lymphatic system with the ultimate formation of lymphomas seems a possibility. On the other hand, Wagner et al have also shown that crystalline silica when injected intrapleurally in rats can cause lymphoproliferation and lymphomas. ${ }^{16} 17$ Thus it is possible that the other ingredients of the Karain dust - those that are not fibrous-caused the lymphomas in our study. There seem to be great differences in the susceptibility of various strains of animals to the development of lymphomas, Wistar rats being most affected. ${ }^{16}$ Swiss albino mice might be such a susceptible strain of animals. These questions necessitate further studies, which are now in progress.

We thank Professors Y Baris and G Ataman for their help and support in the present study.

\section{References}

${ }^{1}$ Baris YI, Sahin AA, Ǒzesmi M, et al. An outbreak of pleural mesothelioma and chronic fibrosing pleurisy in the village of
Karain/Urgüp in Anatolia. Thorax 1978;33:181-92.

${ }^{2}$ Ataman G. The zeolitic tuffs of Cappadocia and their probable association with certain types of lung cancer and pleural mesothelioma. Comptes Rendus d'Academie de Sciences de Paris, Série D, 1978;287:207-10.

${ }^{3}$ Förster H. Eine mineralogisch-petrographische Untersuchung über mögliche Ursachen von Mesotheliomen in Kappadokien Türkei. Zentralblatt Arbeitsmedizin 1982;32:18-27.

${ }^{4}$ Artvinli M, Baris YI. Malignant mesotheliomas in a small village in the Anatolian region of Turkey: an epidemiological study. JNCI 1979;63:17-22.

${ }^{5}$ Rohl AN, Langer AM, Moncure G, Selikoff IJ, Fischbein A. Endemic pleural disease associated with exposure to mixed fibrous dust in Turkey. Science 1982;216:518-20.

${ }^{6}$ Boman G, Schubert V, Svane B, et al. Malignant mesothelioma in Turkish immigrants residing in Sweden. Scand J Work Environ Health 1982;8:108-12.

${ }^{7}$ Baris YI, Saracci R, Simonato L, Skidmore JW, Artvinli M. Malignant mesothelioma and radiological chest abnormalities in two villages in central Turkey. Lancet 1981;i:984-7.

${ }^{8}$ Artvinli M, Baris YI. Environmental fiber-induced pleuropulmonary diseases in an Anatolian village: an epidemiological study. Arch Environ Health 1982;37:177-81.

${ }^{9}$ Mumpton FA. Report on reconnaissance study of the association of zeolites with mesothelioma cancer occurrences in central Turkey. Brockport, New York: Department of the Earth Sciences, State University College, 1979.

${ }^{10}$ Sebastien P, Eng A, Bignon J, Baris YI. Zeolite bodies in human lungs from Turkey. Lab Invest 1981;44:420-5.

${ }^{11}$ Maltoni C, Mikardi F, Movisi L. Pleural mesotheliomas in Sprague-Dawley rats by erionite: first experimental evidence. Environ Res 1982;29:238-44.

12 Suzuki Y. Malignant mesothelioma following intraperitoneal administration of asbestos and zeolite. In: VIth International Pneumoconiosis Conference 1983. Vol 2. Bochum, West Germany: Bergbaugenossenschaft, 1983:1047-51.

${ }^{13}$ Wagner JC. Experimental studies using erionite fibre. In: VIth International Pneumoconiosis Conference 1983. Vol 2. Bochum, West Germany: Bergbaugenossenschaft, 1983:1009.

${ }^{14}$ Wagner JC. The induction of tumours by the intrapleural injections of various types of asbestos dust. In: Severil L, ed. Lung tumours in animals. Proceedings of the 3rd Quadrennial Conference on Cancer, Perugia, 1965. Perugia: Division of Cancer Research, 1966:589-608.

${ }^{15} \mathrm{Kagan} \mathrm{E}$, Jacobson RJ. Lympoid and plasma cell malignancies: asbestos-related disorders of long latency. Am J Clin Pathol 1983;80:14-20.

${ }^{16}$ Wagner MMF, Wagner JC. Lymphomas in the Wistar rat after intrapleural inoculation of silica. JNCI 1972;49:81-9.

${ }^{17}$ Wagner MMF, Wagner JC, Davies R, Griffith DM. Silica-induced malignant lymphocytic lymphoma: incidence linked with strain of rat and type of silica. Br J Cancer 1980;41:908-17. 